\title{
Histological research of hepatoprotective activity of tablets Lavaflam in rats with subchronic hepatitis
}

\author{
M. A. Aslanian ${ }^{1}$, L. A. Bobrytska ${ }^{1}$, N. L. Bereznyakova ${ }^{1}$, O. S. Shpychak ${ }^{1}$, V. I. Hrytsenko ${ }^{1}$, \\ T. A. Germanyuk ${ }^{2}$, T. I. Ivko²
}

${ }^{1}$ National University of Pharmacy, Kharkiv, Ukraine, ${ }^{2}$ National Pirogov Memorial Medical University, Vinnytsia, Ukraine

Key words:

liver diseases, bile duct diseases, histology, Lavaflam.

\section{Zaporozhye} medical journal 2018; 20 (2), 182-187 Dol: 10.14739/2310-1210 2018.2.124940

\section{E-mail:}

shpichak_oleg@ukr.net, germanyuk_vt@ukr.net
Hepatobiliary system diseases are medical and social problem at the present time. Important issue is the development of a new complex of herbal medicine and its pharmacoeconomic study.

The purpose of the work was an experimental substantiation of the hepatoprotective properties of the drug Lavaflam.

Methods of research: pharmacological, morphological, histological, methods of mathematical statistics.

Materials of research. Experimental pharmacological studies were performed on the white rats weighing 180-220 g. The study was carried out in the Central Research Laboratory (CRL) of the National University of Pharmacy, Kharkiv, Ukraine (Certificate № 023/13 of 05.03.2013) according to the methodological recommendations of the State Expert Center of the Ministry of Health of Ukraine. The rats were divided into four experimental groups: the first group - intact control; the second group positive pathology - the animals were injected TChM; the third group - animals, received TChM and Lavaflam; the fourth group - animals, received TChM and reference drug Carsil.

Results. It has been found that the test drug Lavaflam showed hepatoprotective properties in experimental model of the subchronic hepatitis (diffuse inflammatory liver disease) in rats.

Conclusions. Lavaflam, in comparison with Carsil contributed to the elimination and reduction in a number of pathological changes, increased adaptive capacity of hepatocytes, and Lavaflam promoted the physiological regeneration of cells. Relating to the effect of a positive influence on the hepatic parenchyma condition with induced subchronic hepatitis by TChM, the drug Lavaflam was not inferior to the comparison drug Carsil (by the effect on necrotic manifestations), or was superior to the comparison drug Carsil (by the zones of destruction spread, dystrophic changes in hepatocytes).
Киючові слова: захворювання гепатобіміарної системи, гістологічні АосліАження, таблетки Аавафлам.

Запорізький медичний журнал. - 2018. T. 20, № 2(107). C. $182-187$

\section{Аослідження гепатозахисної активності таблеток Аавафлам в умовах субхронічного гепатиту у щурів, що викликаний тетрахлорметаном}

\section{М. А. Асланян, А. О. Бобрицька, Н. А. Березнякова, О. С. Шпичак, В. І. Гриценко, Т. А. Германюк, Т. І. Івко}

Захворювання гепатобіліарної системи становлять чималу медико-соціальну проблему. Актуальним питанням є розробка нового комплексного рослинного лікарського засобу та його фрармакоекономічна оцінка.

Мета роботи - експериментальне обґрунтування гепатопротекторних властивостей препарату Лавафрлам.

Методи дослідження: фрармакологічні, морфологічні, методи математичної статистики.

Матеріали дослідження. Експериментальні фармакологічні дослідження виконали на білих щурах масою 180-220 г. Дослідження виконали в Центральній науково-дослідній лабораторії Національного фармацевтичного університету, м. Харків, Україна (свідоцтво про переатестацію № 023/13 від 05.03.2013р.), згідно з методичними рекомендаціями Державного експертного центру Міністерства охорони здоров'я України. Щурів, яких включили в дослідження, поділили на 4 експериментальні групи: 1 - інтактний контроль; 2 - позитивна патологія, тваринам вводили тетрахлорметан; 3 - тварини, які отримували тетрахлорметан і Лавафрлам; 4 - тварини, які отримували тетрахлорметан і препарат порівняння Карсил.

Результати. Встановили, що тестовий препарат Лавафлам показав гепатопротекторні властивості в експериментальній моделі субхронічного гепатиту (дифузного запального захворювання печінки) в щурів.

Висновки. Лавафолам сприяє зменшенню ряду патологічних змін, підвищенню адаптаційної здатності гепатоцитів, а також фрізіологічній регенерації клітин. За ефектом позитивного впливу на стан печінкової паренхіми при токсичному ураженні ії тетрахлорметаном комбінований Лавафлам або не поступався препарату порівняння Карсилу (за впливом на некротичні прояви), або перевищував його (за поширеністю зон деструкцій, вираженістю дистрофічних змін гепатоцитів).
Кмючевые слова: заболевания пищеварительной системы, гистологические исследования, таблетки Аавафлам.

\section{Исследование гепатопротекторной активности таблеток Аавафлам в условиях субхронического гепатита у крыс, вызванного тетрахлорметаном}

\section{М. А. Асланян, А. А. Бобрицкая, Н. А. Березнякова, О. С. Шпичак, В. И. Гриценко, Т. А. Германюк, Т. И. Ивко}

Заболевания гепатобилиарной системы остаются значительной медико-социальной проблемой. Актуальным вопросом является разработка нового комплексного растительного лекарственного средства и его фрармакоэкономическая оценка.

Цель работы - экспериментальное обоснование гепатопротекторных свойств препарата Лавафрлам. 
Методы исследования: фармакологические, морфологические, методы математической статистики.

Материалы исследования. Экспериментальные фармакологические исследования выполнены на белых крысах массой 180-220 г. Исследования проведены в Центральной научно-исследовательской лаборатории Национального фармацевтического университета, г. Харьков, Украина (свидетельство о переаттестации № 023/13 от 05.03.2013 г.), в соответствии с методическими рекомендациями Государственного экспертного центра Министерства здравоохранения Украины. Крысы, включенные в исследование, были разделены на 4 экспериментальные группы: 1 - интактный контроль; 2 - положительная патология, животным вводили тетрахлорметан; 3 группа - животные, которые получали тетрахлорметан и Лавафлам; 4 - животные, которые получали тетрахлорметан и препарат сравнения Карсил.

Результаты. По результатам исследований установлено, что тестовый препарат Лавафлам показал гепатопротекторные свойства в экспериментальной модели субхронического гепатита (дифффузного воспалительного заболевания печени) у крыс.

Выводы. Лавафлам способствует уменьшению ряда патологических изменений, повышению адаптационной способности гепатоцитов, а также физиологической регенерации клеток. По эффекту положительного влияния на состояние печеночной паренхимы при ее токсическом поражении тетрахлорметаном комбинированный препарат Лавафлам либо не уступал препарату сравнения Карсилу (по влиянию на некротические проявления), либо превышал его (по распространенности зон деструкции, выраженности дистрофических изменений гепатоцитов).

Hepatobiliary system diseases are medical and social problem at the present time as the diseases affect people of all countries and are common to all social strata and to all age groups. According to the current data by WHO hepatobiliary pathology has $30 \%$ of the planet population [1]. In Ukraine the incidence of hepatitis has increased by $76.6 \%$ over the past 10 years and prevalence - in 2.2 times. Mortality has doubled over the past 20 years, and $60 \%$ of patients are people of working age [1]. Hepatoprotective drugs are used for hepatobiliary pathology treatment regardless of the etiology. At the same time, the preparations of plant origin are played a significant role in this process. These preparations are with following herbs: Cynara scolymus, Silybum marianum, Helichrysum arenarium.

In the Ukrainian pharmaceutical market there is the A05 group of the drugs for treatment of hepatobiliary system diseases according to ATC-classification [2]:

1. A05A - drugs used for biliary pathology (Ursodesoxycholic acid, Allocholum, Artihol, Hepabene, Cholosasum, Chophytol, Species cholagogae, Helichrysum arenarium, Flamin);

2. A05B - drugs used for liver diseases, lipotropic substances (Arginine, Silymarin, Carsil);

3. A05C - drugs used for biliary pathology in combination with lipotropic substances (Hepadif, Eslidine).

A new combined herbal drug Lavaflam was developed under the direction of Doctor of pharmaceutical sciences, associate professor Bobrytskaya L. at the Department of Industrial Technology of Drugs in the National University of Pharmacy, Kharkiv (Ukraine). 1 tablet of Lavaflam contains $50 \mathrm{mg}$ of Flamin and $20 \mathrm{mg}$ of Lavender oil, medical form is tablets 0.6 grams № 50 (Table 1) [3]. Lavaflam will be produced by the pharmaceutical company "Zdorovye" (Kharkiv, Ukraine).

Table 1. Composition of the tablets Lavaflam

\begin{tabular}{lll}
\hline Composition & g & \% \\
\hline Lavender oil & 0.02 & 3.34 \\
Beta-cyclodextrin & 0.27 & 45.0 \\
Flamin & 0.05 & 8.33 \\
Mannitol & 0.20 & 3.33 \\
Potato starch & 0.022 & 3.67 \\
Sodium croscarmellose & 0.03 & 5.00 \\
Polyethylene glycol 6000 & 0.002 & 0.33 \\
Magnesium stearate & 0.006 & 1.00 \\
Total & $\mathbf{0 . 6 0 0 0}$ & 100 \\
\hline
\end{tabular}

Analysis of the literature shows hepatoprotective properties of biologically active substances (flavones, flavonols, flavonones and chalcones, oxycinnamic acids, terpene compounds, glycosides, polysaccharides, alkaloid of coumarin etc.), which are the parts of Lavaflam tablets, and their wide application in hepatology [4]. Lavaflam is predicted to have choleretic, antiseptic, antispasmodic, antibacterial, anti-inflammatory effects, to improve the detoxification function of liver, normalize of gallbladder tone, increase biliary tract peristalsis, increase cholagogue activity.

So it made sense to study hepatoprotective properties of Lavaflam tablets and to determine a possibility to use it as a hepatoprotector.

Pharmacological study of the Lavaflam hepatoprotective properties was conducted as a preclinical study on the model of subchronic hepatitis in rats induced by tetrachloromethane (TChM).

The purpose of the study was histological evidence of the drug Lavaflam hepatoprotective properties in the experimental model of subchronic hepatitis.

\section{Research objectives:}

1. Development of experimental model of subchronic hepatitis in rats.

2. Comparison of hepatoprotective properties of Lavaflam and Carsil preparations on the basis of liver cells, portal vein, hepatic artery, hepatic venules, arterioles, sinusoidal hemocapillaries, bile duct epithelium histological examination

Object of study: hepatoprotective properties of Lavaflam tablets.

Methods of research: pharmacological, morphological, histological, methods of mathematical statistics.

\section{Materials of research}

Experimental pharmacological studies were performed on the white rats weighing 180-220 g. The study was carried out in the Central Research Laboratory (CRL) of the National University of Pharmacy, Kharkiv, Ukraine (Certificate № 023/13 of 05.03.2013) according to the methodological recommendations of the State Expert Center of the Ministry of Health of Ukraine [5]. Rats that are included in the study were grown in the vivarium and before the experiment they were acclimated in the room for research during seven days. All studies were performed accordingly with the requirements of the European convention for the protection of
Запорожский медицинский журнал. - 2018. T. 20, № 2(107). C. $182-187$ 


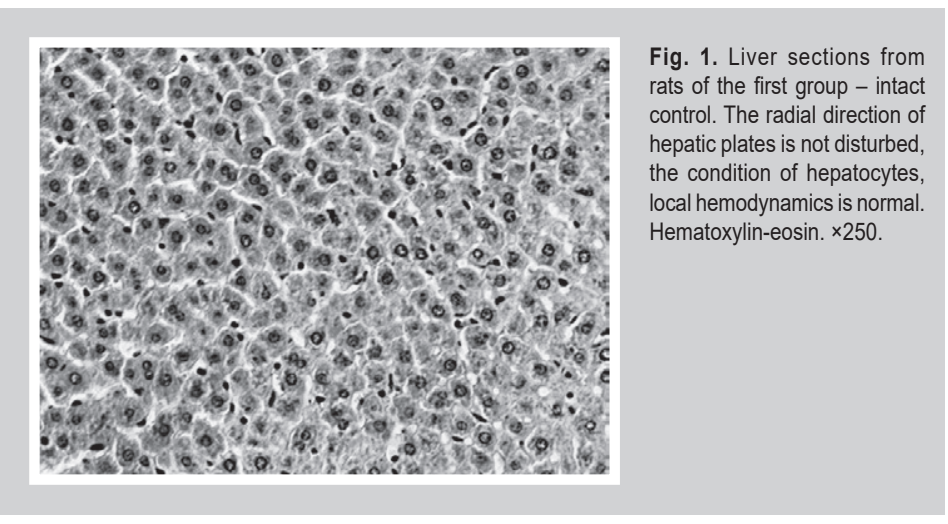

vertebrate animals used for experimental or other scientific purposes [6].

Study of hepatoprotective activity of Lavaflam tablets was performed on the model of experimental subchronic hepatitis in rats caused by the intragastrically introduced TChM in the form of $50 \%$ oil solution in dose of $0.4 \mathrm{ml} / 100 \mathrm{~g}$ of animal weight during 4 days by dint of metal probe [7].

The drug Lavaflam and the reference drug Carsil (Sopharma, Bulgaria, tablet $22.5 \mathrm{mg}$, series F45522) that were used for experimental subchronic hepatitis treatment, were studied on the next day after the pathology modeling. Lavaflam and Carsil tablets were administered prophylactically intragastrically once a day for a week prior to the onset of pathology development formation. In the last days of the experiment (7 days) the introduction was continued in the treatment regimen - intragastrically, once a day, for 4 days and 3 days after the formation of pathology. In general, the course of the studied drugs application was 14 days.

The rats were divided into four experimental groups, 10 animals in each: the first group - intact control; the second group - positive pathology - the animals were injected TChM; the third group - animals, received TChM and Lavaflam in a dose of $50 \mathrm{mg} / \mathrm{kg}$ body weight of the rats; the fourth group - animals, received TChM and reference drug Carsil in a dose of $50-5 \mathrm{mg} / \mathrm{kg}$ body weight of the rats. The doses of Lavaflam and the reference drug Carsil were calculated on the coefficients of species stability by Yu. R. Rybolovlev [8]. All the experiments were carried out according to the requirements of the EC Directions 86/609/EEC November 24,1986 concerning care and use of laboratory animals.

Histological assessment of the liver morphological state was performed. Histological material was fixed in $10 \%$ solution of neutral formalin and it was embedded in celloidin paraffin. Liver slices were stained with hematoxylin and eo$\sin$. Micropreparations were observed with the microscope Granum, microphotographs of images were taken using a digital video camera Granum DSM 310. Photos were processed on a computer Pentium $2.4 \mathrm{GHz}$ using the program Toup View.

The degree of liver damage in comparison with the groups of rats - intact control (the first group of animals) and positive pathology (the second group of rats) was taken into account to assess microscopic changes in the liver. Semi-quantitative assessments of the pathological process and the influence of Lavaflam on it were made on the liver slices. The following signs were evaluated: severity of fatty dystrophy, necrotic manifestations and existence of tissue pattern violation. Sokolovsky's method was taken as the basis for semi-quantitative visual assessment of histochemical changes.

While applying the method of mathematical statistics, the significance level of $p<0.05$ was accepted. In order to obtain conclusions when comparing statistical samples of relative variables, after the single-factor analysis of variance (or the Kruskal-Wallis criterion for data not subject to the normal distribution), differences were found between the experimental groups; the Newman-Keils criteria, the Student's criteria for multiple comparisons or MannWhitney criterion, for nominal data - Fisher's exact criteria were used. For the mathematical calculations the standard statistical software package Statistica 6.0 was used [9].

\section{Results and discussion}

Microscopic examination of experimental animals' liver was performed after autopsy. In animals of intact control (the first group of rats) the liver had not expressive a typical structure segmental pattern of tissue. The segments borders were determined by triads, these zones were narrow. Endothelium conditions of the portal vein, hepatic artery, bile duct terminal branches, which are parts of triads, and other blood vessels, were normal. The radial direction of the hepatic plate system was not disturbed. Hepatocytes had a typical shape and size, distinct cell membranes. The nuclei of cells were oval and centrally located; they contain basically one, at least 2 nucleoli. Cell cytoplasm was uniformly colored; it did not contain any visible corpuscles on the optical level. The content of dual-core cells was normal. The cells that were in some distribution phases were not found in the micropreparate. Sinusoidal capillaries were moderately dilated, sometimes with erythrocytes. The lymphoid cells number in the capillaries was moderate. The condition of stellate reticuloendotheliocytes (Kupffer cells) was normal (Fig. 1).

Explicit violation of the liver parenchyma was found in the rats of the second group (positive pathology group) 3 days after the last TChM administration. The changes were localized in centrolobular and periportal zones of the segments. The destructive zones size varied from $1 / 2$ to $2 / 3$ of hepatic lobules. Sometimes these zones merged with each other (Fig. 2).

We observed discomplexation, hepatic plate's radial direction loss, scattered unicellular necrosis of hepatocytes, pronounced fat and protein degeneration of the cells. Manifestations of inflammatory response were minimal. Terminal hepatic veins were dilated; however sinusoidal capillaries were often compressed and poorly visible. Fatty degeneration in the destruction zones was mainly of medium and microvesicular character, in places small fat cysts were seen. Small groups of activated Kupffer cells were observed among necrotized hepatocytes (Fig. 3).

In the restricted parts of the lobules (the intermediate zone of the liver acini), the hepatic parenchyma was relatively retained. Hepatocytes of such zones were often swollen with blurred cell borders and fine cytoplasmic vacuolization. The radial direction of cells was not clear. There was a noticeable decrease in dual-core cells. At the same time, manifestations of regenerative processes in the form of moderate anisonucleosis were observed (Fig. 4). 

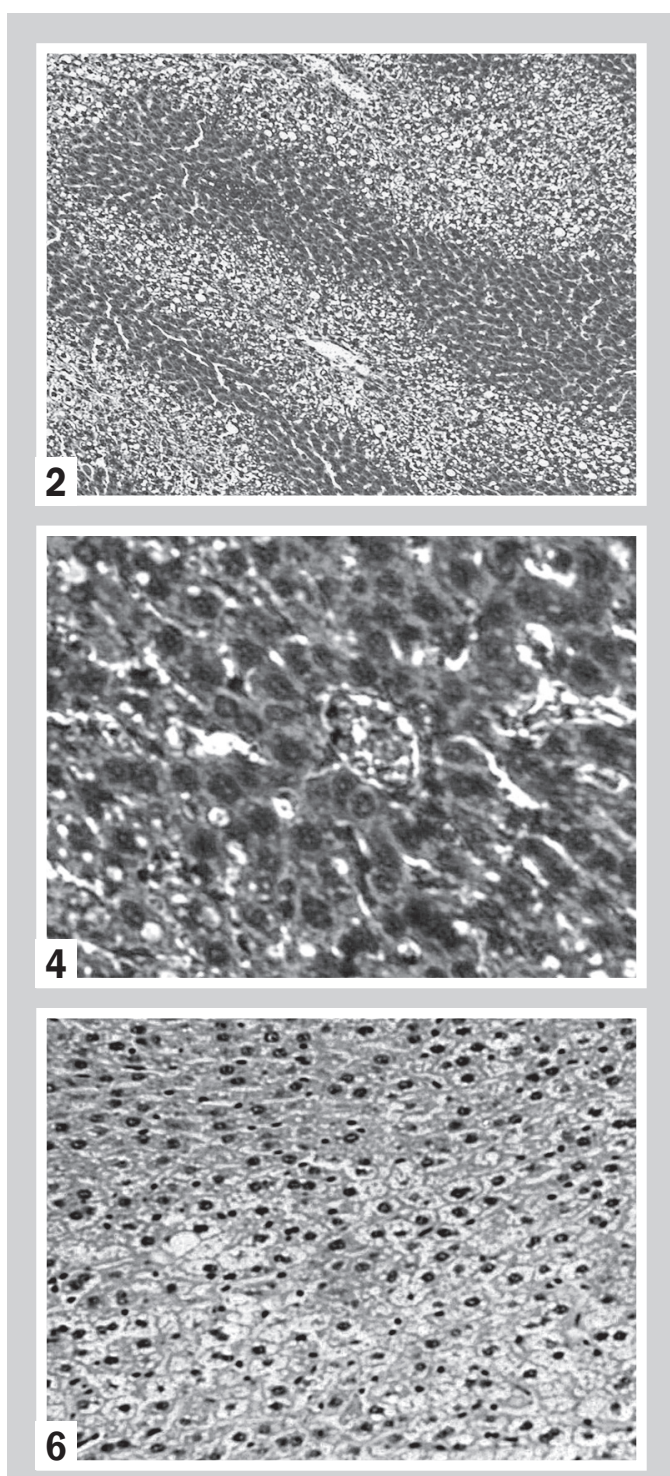

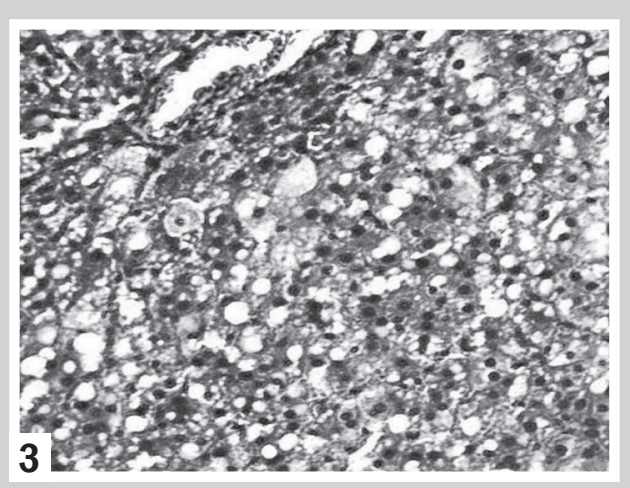

Fig. 2. Liver sections from rats after administration of TChM. Violation of liver parenchyma structural organization predominantly in centrolobular and periportal zones. Hematoxylin-eosin. $\times 250$.

Fig. 3. Liver sections from rats after administration of TChM. Violation of the hepatic plates, fatty and protein degeneration of hepatocytes, monocellular necrosis of some cells, minimal manifestations of inflammation. Hematoxylin-eosin. $\times 250$.

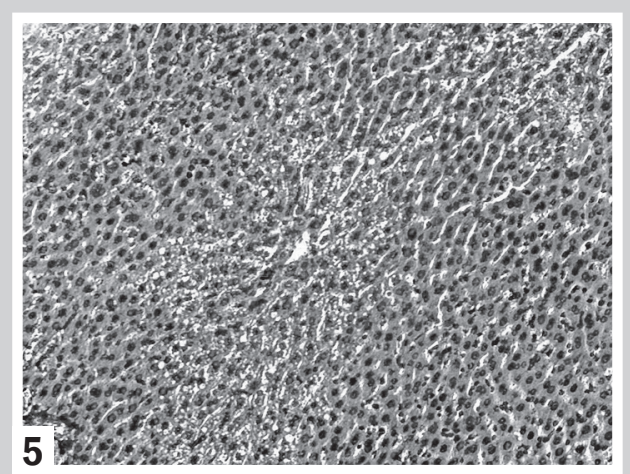

Fig. 4. Liver sections from rats after administration of TChM. Swelling of hepatocytes, fine cytoplasmic vacuolization, blurred cell borders. Hematoxylin-eosin. ×250.

Fig. 5. Liver sections from rats with induced subchronic hepatitis by TChM after administration of Lavaflam. Significant reduction of damaged zones in the liver. Hematoxylin-eosin. $\times 250$.

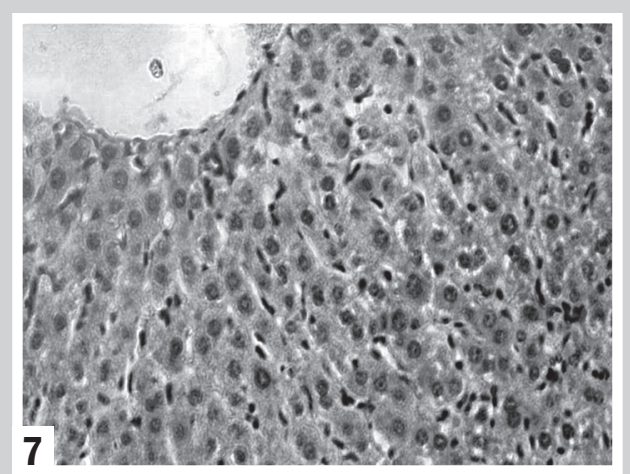

Fig. 6. Liver sections from rats with induced subchronic hepatitis by TChM after administration of Lavaflam. Microvesicular fatty dystrophy of hepatocytes without disruption of cell integrity. Hematoxylin-eosin. $\times 250$.

Fig. 7. Liver sections from rats with induced subchronic hepatitis by TChM after administration of Lavaflam. It was established restoration of the radial pattern of hepatocyte strands, expressive anisonucleosis, the pool of binuclear cells was increased. Hematoxylin-eosin. $\times 250$.
In the group of animals that received TChM and Lavaflam (the third group of rats) we observed significant improvement of the hepatic parenchyma structural organization in most animals. Destruction zones are clearly reduced (Fig. 5).

Actually, it has been noted no protein degeneration of hepatocytes, fat dystrophy was reduced, there were fine vesicles, they do not violate cell integrity and fatty cysts were absent. Necrosis was in a small number of cells. Microcirculation was improved (Fig. 6).

Hepatocytes on unchanged parts of the segments kept the radial direction in hepatic plates, they were morphologically more complete. The pool of dual-core cells was enlarged. We observed polymorphism of cells and nuclei and a lot of polyploid cells. They had an increased in size nucleus and cytoplasm, and hyperchromias were observed in them an increase in the amount of chromatin in the nucleus (Fig. 7). This indicated a physiological regeneration of the liver. Moreover, the increase in the number of binuclear cells was regarded as an increase in their adaptive capabilities as they synthesize more protein than single-nucleated cells.

In the group of animals with induced subchronic hep- atitis by TChM after administration of the reference drug Carsil (the fourth group of animals) there was a more noticeable fluctuation in the prevalence of the hepatic lobules parenchyma pattern zones of disturbance. Hepatocytes had middle-vesicular fatty degeneration in destructive zones. Protein dystrophy was not found in all animals. Necrotic cell changes were minimal. Outside the zones of hepatocytes destruction were morphologically more complete. Swelling of the cells was absent, cell membranes were distinct and cytoplasm vacuolation was not expressed. It was found that anisonucleosis was moderate, binuclear cells were noticeable in various zones of lobules in sufficient quantity. Vascular disorders, cellular response were not expressive in all animals (Fig. 8).

It has been revealed that Lavaflam significantly reduced the zones of destruction, the severity of hepatocytes fatty degeneration and necrotic manifestations. According to the expressive influence on necrotic manifestations, Lavaflam is not inferior to the drug of comparison Carsil and ahead of it in its effect on the destruction zones prevalence, and shows a tendency to reduce changes in lipid metabolism (Table 2). 

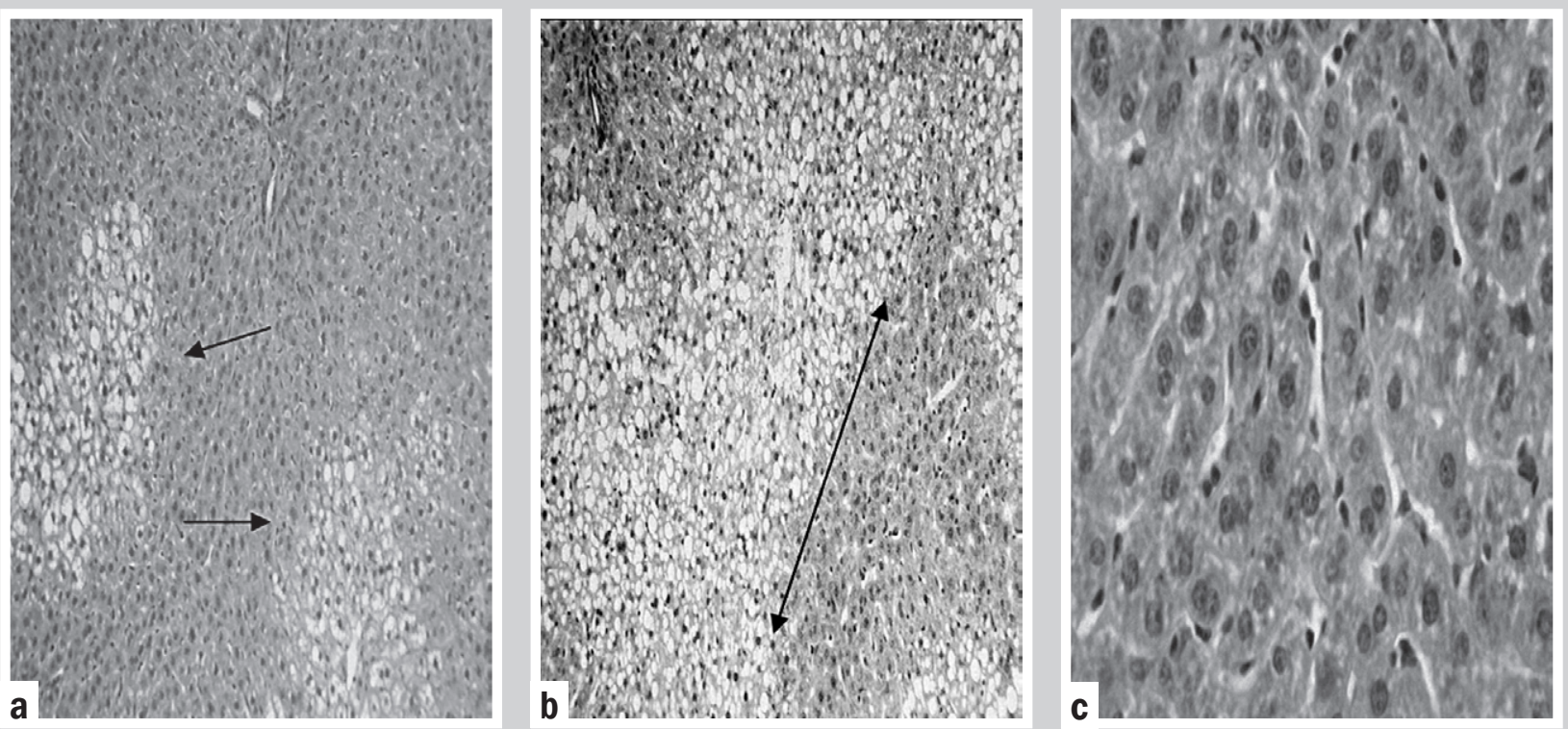

Fig. 8. Liver sections from rats with induced subchronic hepatitis by TChM after administration of Carsil.

Zones of destruction different distribution: $a$ - moderate; $b$ - large; $c$ - normal hepatocytes outside the zones of destruction. Hematoxylin-eosin. $a, b: \times 100, c: \times 250$.

Table 2. Correction by combined drug Lavaflam of pathological process in liver parenchyma of rats with TChM lesion (balls, Me (LQ;UQ))

\begin{tabular}{|c|c|c|c|}
\hline \multirow[t]{2}{*}{ Experiment group } & \multicolumn{3}{|l|}{ Index } \\
\hline & Severity of fatty dystrophy & Necrotic changes in hepatocytes & Prevalence of destructive zones \\
\hline Intact control $(n=6)$ & $0(0 ; 0)$ & $0(0 ; 0)$ & $0(0 ; 0)$ \\
\hline Positive control (TChM) $(n=6)$ & $3(3 ; 4)^{*}$ & $2(1 ; 2)^{*}$ & $3(2 ; 3)^{*}$ \\
\hline Lavaflam + TChM $(n=6)$ & $1(1 ; 2)^{* / * \star \ldots / \ldots(P=0.0823)}$ & $1(0 ; 1)^{* *}$ & $1(1 ; 1)^{* / * k \mid * \star *}$ \\
\hline Carsil + TChM (n=5) & $2(2 ; 3)^{\star / * \star *}$ & $1(0 ; 1)^{* *}$ & $2(2 ; 2)^{*}$ \\
\hline
\end{tabular}

*: differences are statistically significant with respect to the group of intact control (the first group of rats) at the level of significance $P \leq 0.05$ (Mann-Whitney criterion);

**: differences are statistically significant with respect to the group of positive pathology (the second group of rats) at the level of significance $P \leq 0.05$ (Mann-Whitney criterion);

${ }^{* * *}$ : differences are statistically significant with respect to the group of rats with induced subchronic hepatitis by TChM after administration of Carsil (the fourth group of rats)

at the level of significance $\mathrm{P} \leq 0.05$ (Mann-Whitney criterion); ' ': tendency towards statistically significant differences in the group of rats with induced subchronic hepatitis by TChM

after administration of Carsil (the fourth group of rats) at the level of significance $0.05>P<0.1$ (Mann-Whitney criterion); n: number of animals in the experimental group.

\section{Conclusions}

1. Four-fold intragastric administration of TChM caused the acute toxic lesion in rat liver - subchronic hepatitis.

2. The test drug Lavaflam showed hepatoprotective properties in the subchronic hepatitis experimental model.

3. Lavaflam, in comparison with Carsil, contributed to a number of pathological changes reduction and elimination, increased adaptive capacity of hepatocytes, and Lavaflam promoted the physiological regeneration of cells.

4. Relating to the effect of a positive influence on the hepatic parenchyma condition with induced subchronic hepatitis by TChM, the drug Lavaflam was not inferior to the comparison drug Carsil (by the effect on necrotic manifestations), or was superior to the comparison drug Carsil (by the zones of destruction spread, dystrophic changes in hepatocytes).

\section{References}

[1] Mykhailiuk, Ye. O. (2015). Farmakolohichna aktyvnist novykh pokhidnykh 4-r-5-(alkil-, aryl-,heteryl-)-1,2,4-triazolu pry eksperymentalnomu toksychnomu hepatyti (Avtoref. dis...kand. tekh. nauk). [Pharmacological activity of new derivatives of 4-r-5- (alkyl-, aryl-, heteryl) -1,2,4-triazole in experimental toxic hepatitis]. (Extended abstract of candidate's thesis). Zaporizhzhia [in Ukrainian].
[2] (2017) WHOCC-ATC / DDD Index. Retrieved from https://www.whocc. no/atc ddd index.

[3] Bobryts'ka, L.A., Arakelyan, M.A., Popova, N.V. (2014). Marketynhove doslidzhennya rynku likiv z zhovchohinnoyu diyeyu [Marketing research of the market of drugs with the choleretic action]. Visnyk farmatsiyi, 2, 63-67. [in Ukrainian].

[4] Aslanyan, M. A. (patentee), Bobrytska, L., Honcharov, M. I., Nazarova, E. S., Popova, N. V., \& Lytvynenko, V. I. (2015) Patent 97298 Ukrayina, MPK A $61 \mathrm{~K}$ 36/53. Likarskyi zasib zhovchohinnoho efektu [Patent 97298 Ukraine, IPC A 61 K 36/53. Medicinal product of choleretic effect]. Bulleten, 5. [in Ukrainian].

[5] Bobrytska, L. A., Arakelian, M. A., \& Popova, N. V. (2014) Marketynhove doslidzhennia rynku likiv z zhovchohinnoiu diieiu [Market research of the market of medicines with choleretic effect]. Visnyk farmatsii, 2(78), 63-67. [in Ukrainian].

[6] Stefanov, O. V. (ed) (2001). Doklinichni doslidzhennia likiv [Preclinica research of medicines]. Kyiv: Avitsenna [in Ukrainian].

[7] (1986). European convention for the protection of vertebrate animals used for experimental and other scientific purposes. Council of Europe, Strasbourg.

[8] Pozdniakov, V. S., \& Ivanov, N. H. (1979). Zmina funktsionalnoho stanu shchuriv pid vplyvom tetrakhlorydu vuhletsiu [Changing the functional state of rats under the influence of carbon tetrachloride]. Toksykolohiia novykh promyslovykh khimichnykh substantsii, 15, 87-90 [in Ukrainian].

[9] Rybolovlev, Yu. R., \& Rybolovlev, R. S. (1979). Dozirovanie veshhestv dlya mlekopitayushchikh po konstantam biologicheskoj aktivnosti [Dosage of substances mammals on biological activity constants]. Doklady AN SSSR, 247(6), 1513-1516 [in Russian].

[10] Halafyan, A. A. (2007) STATISTICA 6. Statisticheskij analiz danykh [Statistics 6. Statistical analysis of data]. Moscow: Binom Press [in Russian]. 


\section{Information about authors:}

Aslanian M. A., PhD Student, Department of Industrial Technology

of Drugs, National Pharmaceutical University, Kharkiv, Ukraine.

Bobrytska L. A., Dr. hab., Associate Professor, Department

of Industrial Technology of Drugs, National Pharmaceutical

University, Kharkiv, Ukraine.

Bereznyakova N. L., Dr. hab., Professor, Department of Medicinal

Chemistry, National Pharmaceutical University, Kharkiv, Ukraine.

Shpychak O. S., Dr. hab., Professor, Department of Drug

Technology named after D. P. Salo, National University

of Pharmacy, Kharkiv, Ukraine.

Hrytsenko V. I., Dr. hab., Associate Professor, Department

of Industrial Technology of Drugs, National Pharmaceutical

University, Kharkiv, Ukraine.

Germanyuk T. A., MD, PhD, DSc, Professor, Pharmacy

Department, Vinnytsia National Pirogov Memorial Medical

University, Ukraine.

Ivko T. I., PhD, Associate Professor, Pharmacy Department,

Vinnytsia National Pirogov Memorial Medical University, Ukraine.

\section{Відомості про авторів:}

Асланян М. А., зАобувач каф. заводської технології ліків,

Національний фармацевтичний університет, м. Харків, Україна.

Бобрицька ^. О., А-р фарм. наук, Аоцент каф. заводської

технології ліків, Національний фармацевтичний університет,

м. Харків, Україна.

Березнякова Н. ^., А-р фарм. наук, професор каф. медичної хімії, Національний фармацевтичний університет, м. Харків, Україна.

Шпичак 0. С., А-р фарм. наук, професор каф. аптечної

технології ліків імені А. П. Сала, Національний фармацевтичний університет, м. Харків, Україна.

Гриценко В. І., А-р фарм. наук, Аоцент каф. заводської технології ліків, Національний фармацевтичний університет, м. Харків, Україна.

Германюк Т. А., А-р меА. наук, професор каф. фармації,

Вінницький національний медичний університет

імені М. І. Пирогова, Україна.

Івко Т. І., канА. фарм. наук, доцент каф. фармації Вінницького національного медичного університету імені М. І. Пирогова,

Україна.

\section{Сведения об авторах:}

Асланян М. А., соискатель каф. заводской технологии лекарств, Национальный фармацевтический университет, г. Харьков, Украина.

Бобрицкая ^. А., А-р фарм. наук, Аоцент каф. завоАской технологии лекарств, Национальный фармацевтический университет, г. Харьков, Украина.

Березнякова Н. ^., А-р фарм. наук, профессор каф. медицинской химии, Национальный фармацевтический университет, г. Харьков, Украина.

Шпичак О. С., А-р фарм. наук, профессор каф. аптечной технологии кекарств имени А. П. Сало, Национальный фармацевтический университет, г. Харьков, Украина. Гриценко В. И., А-р фарм. наук, Аоцент каф. завоАской технологии мекарств, Национальный фармацевтический университет, г. Харьков, Украина.

Германюк Т. А., А-р меА. наук, профессор каф. фармации, Винницкий национальный медицинский университет имени Н. И. Пирогова, Украина.

Ивко Т. И., канА. фарм. наук, Аоцент каф. фармации, Винницкий национальный медицинский университет имени Н. И. Пирогова, Украина.

Conflicts of Interest: authors have no conflict of interest to declare. Конфмікт інтересів: віАсутній. 